\title{
The Environmental Sanitation Risk Assessments based on Public Participation to the Sanitation Management in Residence in Urban Areas of Mojokerto City
}

\author{
${ }^{1}$ Mohammad Debby Rizani, ${ }^{2}$ Antariksa, ${ }^{3}$ Surjono and ${ }^{3}$ Ismu Rini Dwi Ari \\ ${ }^{1}$ Department of Civil Engineering, \\ ${ }^{2}$ Department of Architecture, \\ ${ }^{3}$ Department of Urban and Regional Planning, Faculty of Engineering, \\ University of Brawijaya, Jl. Veteran, 65145 Malang, Jawa Timur Province, Indonesia \\ dunia_reza@yahoo.co.id
}

\begin{abstract}
The condition of sanitation services in Mojokerto City up to 2017 was $78 \%$. Mojokerto City has been attempting to provide appropriate sanitation services, yet it has been hampered by political interests, sectoral interests, lack of human resources and sanitation facilities, limited land and low public and private participation. This study is aimed to determine the level of public participation based on an environmental sanitation risk assessment using descriptive qualitative and quantitative methods. The data collection is done using questionnaires, interview, observation and primary as well as secondary data collection. The planning method in the analysis of sanitation risk assessment is the methodology for participatory assessments, that is to conduct an assessment of public development management. The environmental sanitation risk assessment produce sanitation risk index collected from the result of a participative survey in Mojokerto City to acknowledge the sanitation facilities and public attitude toward hygiene and sanitation in the scope of household. The level of public participation is on the contrary with the final value of sanitation risk index in the domestic wastewater management and household waste. Spatially, a spatial interactive approach applied in an adjacent area will be very influential to other areas, also by applying spatial comparative approach, it can be described the comparison of one area and other areas in terms of domestic wastewater management or household waste.
\end{abstract}

Key words: Sanitation risk assessments, public participation, spatial approach, spatial comparative, sanitation facilities, wastewater management

\section{INTRODUCTION}

The sanitation management of developing countries is hampered by public interests, as well as economic, ecological and social inequalities. The urban sanitation constitutes one of the most significant challenges in services provision related to poverty alleviation and sustainable development in developing countries (Anonymous, 2010; Luthi et al., 2010).

The problems of sanitation management in Mojokerto City, based on the survey and interview with several respondents as well as documents of sanitation planning, the data collected include: the condition of sanitation services in Mojokerto City up to 2017 was still 78\%; the ownership of water closet with secured septic tank was $25.4 \%$, do not have Fecal Treatment Plant (IPLT-instalasi pengolahan lumpur tinja) had not reached ODF (Open Defecation Free) or free defecation (BABS-Buang Air
Besar Sembarangan) with a number of family who BABS as many as 2,338 family; a part of the population that dump wastes to body of water/river, the quota of waste processing site (TPA-Tempat Pemrosesan Akhir) had been overloaded, lacking transport facilities, puddles with a width of 103 ha over 1-2 h, lack of public awareness of healthy and clean living behavior (PHBS-Perilaku Hidup Bersih Dan Sehat), limited resources and funding from the government for sanitation management and the absence of regional regulations regarding wastewater and garbage.

The city Government of Mojokerto has been attempting to provide appropriate sanitation services, yet it has been hampered by political interests, sectoral interests, lack of human resources and sanitation facilities, limited land and low public and private participation. The government as the policy-maker indeed is a responsible one for inappropriate sanitation problems in urban areas

Corresponding Author: Mohammad Debby Rizani, Department of Civil Engineering, Faculty of Engineering, University of Brawijaya, Jl. Veteran, 65145 Malang, Jawa Timur Province, Indonesia, dunia_reza@yahoo.co.id 
(Ginige et al., 2010). It requires synergy, intersectoral collaboration and public participation to support the sanitation development in order to accomplish the targeted sanitation services. The good and proper sanitation management is one of the public health support factors, yet, not every stakeholder give adequate attention to sanitation, either from the government or the public and private party. Therefore, the sanitation management which is technocratically planned with a variety of programs and activities needs to be supported by an increase in public participation to optimize the proper sanitation services (Rizani, 2016).

The issue that has become the focus of this study is the environmental sanitation risk assessment based on public participation to the sanitation management in urban areas of Mojokerto City. This study on sanitation management is limited to the field of domestic wastewater and household waste.

Literature review: In the context of development, participation refers to an active process wherein the beneficiaries influence the direction and implementation of the development projects instead of partly benefitting from the projects (Kombaitan, 1998). This definition reveals two primary aspects which are an active process and the beneficiaries influencing the direction and implementation of the development projects. In public participation, there is a process that goes actively where the public contribute to the direction and implementation of the projects, so that, it is not limited only to contributing time, energy and funds (Mardikanto, 1988).

Participation is a dynamic and multidimensional model in a variety of forms that undergo changes during and after the project cycle in accordance with the interest and need. One of the indicators used to assess the participation is the condition of infrastructures. The more participation there is the better the condition of the infrastructures will be. The condition of infrastructures can be measured from whether it functions or not as well as either it is broken or not. Yet, a poor condition of infrastructures cannot be entirely caused by the lack of participation, yet it can also be caused by errors in the planning and implementation.

Participation is related closely to the implementors involved in it. It is a form of mutual relationship for the implementers including the government and public (Nurcholis, 2009). Furthermore, in that relationship, the government needs to admit the public's potentials as an innovator. If the public is active, the government will only act as a facilitator. Meanwhile, if the public is not, the government will persuade the public to participate.
Besides, the implementers (professional, private party) should give a chance to the public to participate in the planning process, allocation of resources and project implementation.

According to Riyadi and Bratakusumah (2004) there are two obstacles in developing the participative development in Indonesia. The first one is the misconception of the true definition of participation by the development planners and implementers. The second is the feedback coming from the public due to the implementation of development as the new ideology.

The planning method in the analysis of sanitation risk assessment is the methodology for participatory assessments. According to Dayal et al. Methodology for Participatory Assessments (MPA) is a method developed to assess the management of community development. MPA is a useful tool for policy-makers, program manager and people, so that, the local community can monitor the development synergy and take necessary actions in order to be better. The methodology reveals the roles of women and family that are less capable of participating and benefitting from the development together with men and family where they are.

In this study, the participation assessment method used is the environmental sanitation risk assessment. The sanitation risk index is the analysis result of environmental sanitation risk assessmentthat was acquired from the result of a participative survey in a district/city that is aimed to investigate the sanitation facilities and public attitude toward hygiene and sanitation in the scope of households. The sanitation risk index gives an overview qualitatively on the sanitation risks in the community.

\section{MATERIALS AND METHODS}

In conducting this study, the researcher used an approach of qualitative and quantitative methods. This method is chosen because the researcher intended to understand deeply the process of planning in residential sanitation management (Arikunto, 2006). The object observed is the condition of the existing management and level of sanitation services in Mojokerto City.

In order to acknowledge the level of public participation in environmental sanitation management, the researcher conducted an analysis of environmental sanitation risk assessment. The sanitation risks are defined as the decrease in the quality of life, health, constructions and environment due to the low access toward services in the sectors of sanitation and behavior of hygiene and sanitation. The method of data collection 
in this study includes observation, questionnaires, interview and primary and secondary data collection. The total number of sample is based on the limitation from Slovin in Sevilla with the following formulation:

$$
\mathrm{n}=\mathrm{N} /\left(1+\mathrm{N}(\lambda)^{2}\right)
$$

Note:

$\mathrm{n}=$ No. of samples

$\mathrm{N}=$ No. of population $(141,824$ individuals $)$

$\lambda=$ Tolerable percentage leeway inaccuracy due to the sampling $(5 \%)$

$$
\begin{aligned}
& n=141,824 /\left(1+141,824(0.05)^{2}\right)= \\
& 397.76 \approx 400 \text { individuals }
\end{aligned}
$$

An analysis by Anonymous (2016, 2017) environmental sanitation risk assessments using the program tools of DOS Box 0.74, Epi Data 3.1, SPPS 17 and MS Excel 2010 with variables: domestic wastewater risks, consisted of 3 sub-variables such as: safe septic tank suspects, pollution due to the disposal of septic tank contents and pollution due to the system of waterwaste management (SPAL, Sistem Pengolahan Air Limbah). The indicators of assessment consist of.

Safe: A septic tank ownership, since, the beginning of residency, planned septic tank draining, draining done by professionals and grey water is transferred to septic tank.

Not safe: A septic tank ownership not, since, the beginning of residency, unplanned septic tank draining, draining done by non-professionals and water grey is not transferred to septic tank.

Waste risks consists of 4 sub-variables including: waste management, the frequency of waste disposal, timing accuracy of waste disposal and local waste management. The assessment indicators are:

- Adequate provided garbage containers, scheduled waste transport, household waste separation and household waste recycling

- Inadequate no garbage containers provided, unplanned waste transport, no household waste separation and no household waste recycling

\section{RESULTS AND DISCUSSION}

Mojokerto City has a width area of 1,646 ha is the only city in East Java that has the smallest area unit with an administrative area divided only into three subdistricts, namely Prajuritkulon, Magersari and
Kranggan, 18 administrative villages, 65 neighborhood association, 176 citizens association and 72 villages (Anonymous, 2017).

The area of Mojokerto City is thoroughly in the Brantas watershed (DAS, Daerah Aliran Sungai) which is a strategic national watershed. Meanwhile, Brantas River area consisted 4 DAS including Brantas DAS, Tengah DAS, Ringin Bandulan DAS and Kondang Merah DAS and has 9 Sub-DAS such as Brantas Hulu Sub-DAS, Brantas Tengah Sub-DAS, Ngrowo/Ngasinan Sub-DAS, Konto Sub-DAS, Widas Sub-DAS, Brantas Hilir Sub-DAS, Tengah Sub-DAS, Ringin Bandulan Sub-DAS and Kondang Merak Sub-DAS. The DAS in Mojokerto City. The longest and widest river in Mojokerto City is Brantas River with a length of $11,088,661 \mathrm{~m}$ and a width of $733,247.014 \mathrm{~m}^{2}$. According to Sub-DAS, Mojokerto City is in the Brantas Hilir Sub-DAS including the areas of administrative villages of Gunung Gedangan, Meri, Miji, Balongsari, Jagalan, Sentanan, Purwotengah, a part of Mentikan, Kauman, Gedongan, Magersari, Wates and Kedudung.

The number of population of Mojokerto City, based on Mojokerto City in 2015 is 141,824 individuals consisted of 70,310 males and 71,514 females. The average population density of Mojokerto City is 8,616 individuals per $\mathrm{km}^{2}$. Meanwhile, the population density according to the established width area is 157.38 individuals/ha. The number of poor population in Mojokerto City is in total 8,226 families, 4,260 families in Prajurit Kulon Subdistrict and 3,966 families in Magersari Subdistrict.

The access to sanitation services in Mojokerto City in 2017 for the domestic waterwaste field was $90.45 \%$ and household waste was $87 \%$. It leaves an issue in sanitation management to achieve $100 \%$ sanitation services in 2018 that is mandated by the government. With the rising trend of sanitation services up to a maximum of $2 \%$ annually in Mojokerto City. The current data on sanitation services management of Mojokerto City.

Domestic water waste: The number of water closet ownership is $96.2 \%$, the coverage of centered-SPALD services in the communal scale of $2.9 \%$, ownership of water closet with a safe septic tank of $25.4 \%$ do not yet have regional regulations regarding waterwaste has Mayor Regulation No.1 of 2015 regarding STBM and do not yet have fecal treatment plant (IPLT-Instalasi Pengolahan Lumpur Tinja).

Household waste: It has a garbage cart as many as 185 units, 2 units of pick up, 11 units of containers, 4 unit of transfer stations, 5 units of dump trucks, 7 units of arm rol trucks, 3 units TPST, heavy equipment: 2 units of 
bulldozers, 1 unit of truck loader, 2 units of excavators; proper waste management up to $89.3 \%$; has waste masterplan of 2013 has regional Regulation No. 10 of 2010 regarding waste retribution yet has not been effectively implemented has Mayor Regulation No. 1 of 2015 regarding STBM and waste reduction of $7.4 \%$

In sanitation management, the role of the community is necessary to improve the services. The public participation in the development can be started from the planning process up to the implementation of the development itself. In the planning process, it is the highest public involvement. In order to acknowledge the level of public participation in environmental sanitation management, the researcher conducted an analysis of environmental sanitation risk assessment in understanding the condition of sanitation facilities and sanitation hygiene behavior in the household scale that produced a Sanitation Risk Index (IRS). The sanitation risks are defined as the decrease in the quality of life, health, constructions and environment due to the low access toward services in the sectors of sanitation and behavior of hygiene and sanitation.

The results of analysis on questionnaires, interviews and observation regarding the domestic waterwaste management are:

The liquid waste of grey water in Mojokerto city with the basic SPAL sanitation ownership shows a number of families who has SPAL is $86.30 \%$, therefore, there is still $13.70 \%$ who do not yet have SPAL. About $99.40 \%$ of the SPAL is a waterproof drainage channel and the rest is disposed through channels that are not waterproof/to the home yard. The total production of household liquid waste reaches $70-80 \%$ from the clean water use wherein the average is on $100 \mathrm{~L} /$ individual/day. With Mojokerto City's population in 2016 as many as 151,091 individuals, then the production of liquid was is $10,576,400 \mathrm{~L}$ /dayor $10,576 \mathrm{~m}^{3} /$ day.

Defecation to private water closet of $93.3 \%$, in public $\mathrm{MCK} / \mathrm{WC}$ of $2.9 \%$ and BABS of $3.8 \%$ (helicopter $\mathrm{WC}$, river, parks, sewer).

The most number of defecation to private water closet is in the administrative villages of Kauman, Blooto, Surodinawan, Gedongan and Purwotengah which is $100 \%$. Meanwhile, the most BABS is in Mentikan administrative village as much as $7.5 \%$, followed by the administrative villages of Prajurit Kulon, Magersari, Balongsari, Gunung Gedangan, Kranggan and Sentanan with 5\%, respectively.

The final fecal transfer in Mojokerto City is channeled through six places including $86 \%$ to the septic tank, $3.8 \%$ to rivers, $2.4 \%$ to drainage, $0.4 \%$ to sewer pipes, $0.1 \%$ to ground holes and $7.4 \%$ other responses.
The final fecal transfer in administrative villages level, the most to the septic tank is in the administrative villages of Surodinawan, Wates, Meri and Purwotengah as much as $100 \%$. Meanwhile, the least is in Sentanan administrative village with $62.5 \%$ using a septic tank as the final fecal transfer.

From $86 \%$ of the respondents who dispose feces to the septic tank, $59.6 \%$ never did draining, $12.9 \%$ had it drained $1-5$ years ago, $8.2 \%$ between $5-10$ years, $4.2 \%$ had it drained in $<5$ years ago. About $100 \%$ of the respondents in Surodinawan administrative village has never done septic tank draining. Meanwhile, Jagalan administrative village does draining most frequently within up to 10 years which is $61.1 \%$.

The respondents who drain the septic tank in Mojokerto City is $54.8 \%$ did it by stool suction, the rest did it by paying workmen and emptying it themselves. Meanwhile, in Mentikan administrative village, $72.7 \%$ of the respondents admitted that their septic tanks are drained using stool suction service.

The safe septic tank is $41.5 \%$ while the rest $58.5 \%$ is an unsafe septic tank. Meanwhile, at the level of the administrative village, the highest possession of safe septic tank is in Mentikan and Prajurit Kulon administrative villages which is $60 \%$.

The domestic waterwaste management system of Mojokerto City consisted of three systems such as: direct disposal system (basic access and BABS), local domestic waterwaste management system (SPALD-S) and centered domestic waterwaste management system (SPALD-T).

Mojokerto City has not accomplished ODF (Open Defecation Free) or free BABS, this can be seen from the number of families who BABS as many as 2,338 families.

The result of analysis on safe septic tank suspects, pollution due to draining of septic tank contents and pollution due to waterwaste management system (SPAL) are (Fig. 1-3):

Based on the data above, conducted an analysis of sanitation risk assessment in the domestic waterwaste management with a result in forms of value and risk index mapping (Fig. 4).

The clarification of domestic waterwaste sanitation risk index using likert scale is: maximum limit: 91; minimum limit: 25 ; interval: $(91-25) / 4=66 / 4=16.5 \approx 7$ (Fig. 5):

- Low risk: 25-42 (Green)

- Medium risk: 43-59 (Blue)

- High risk: 60-76 (Yellow)

- $\quad$ Very high risk: 77-91 (Red) 
J. Eng. Applied Sci., 14 (24): 9562-9572, 2019

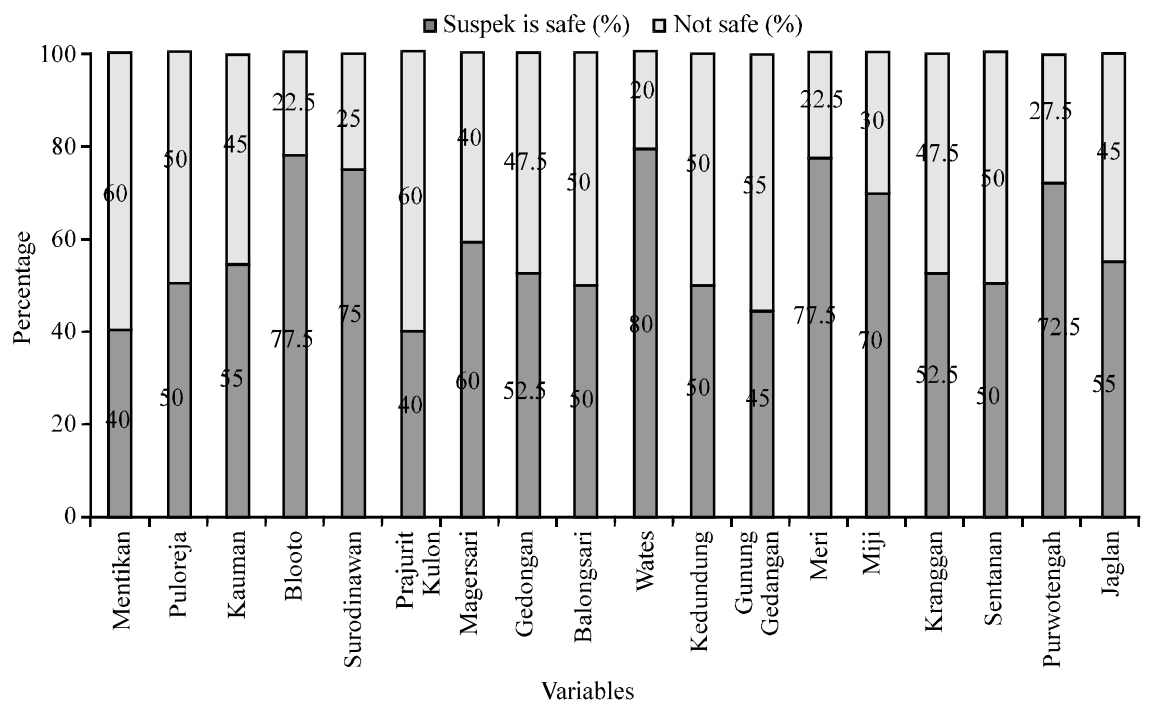

Fig. 1: Graphic of safe and unsafe septic tank

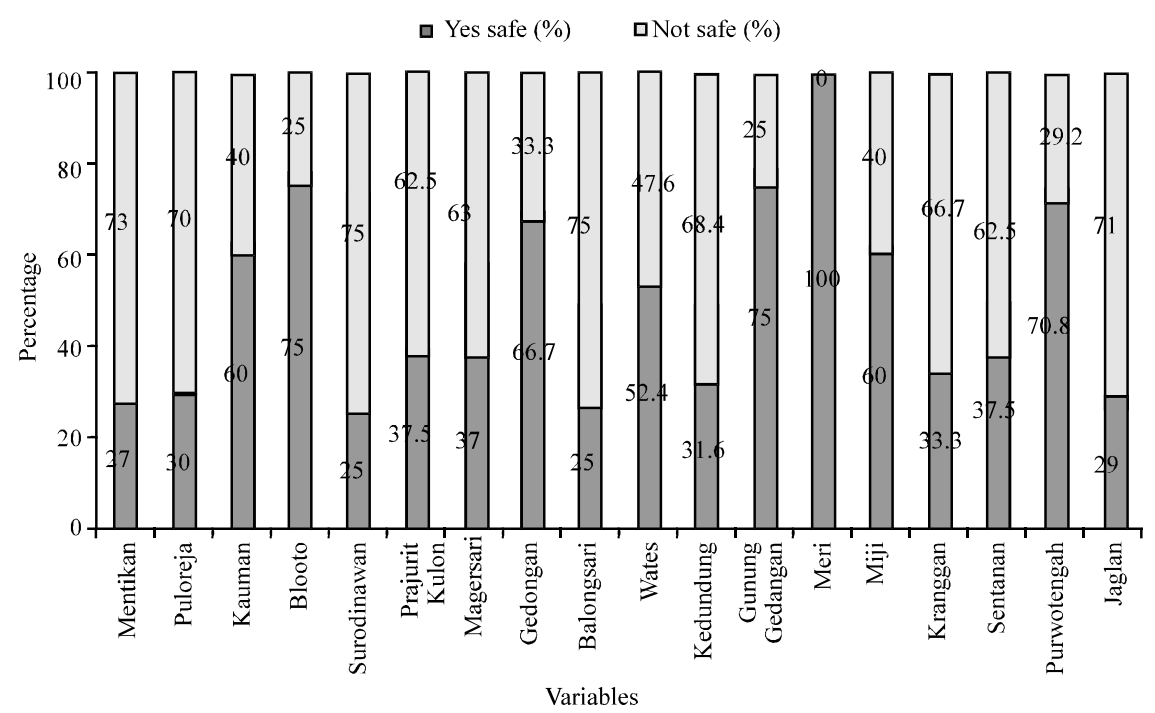

Fig. 2: Graphic of pollution due to septic tank contents disposal

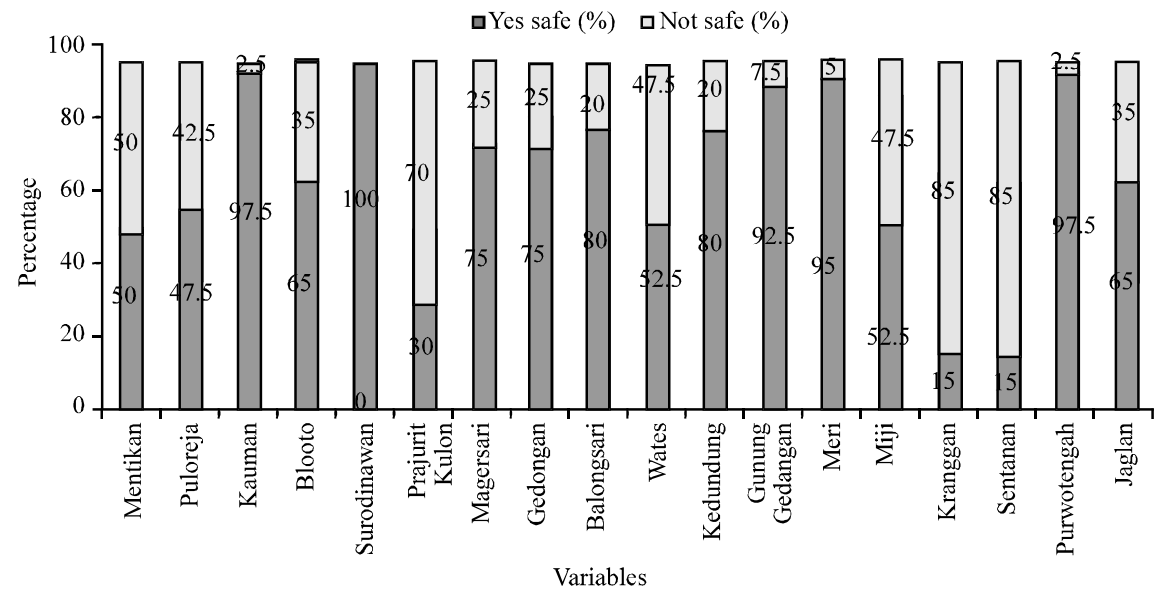

Fig. 3: Graphic of safe and unsafe septic tank 


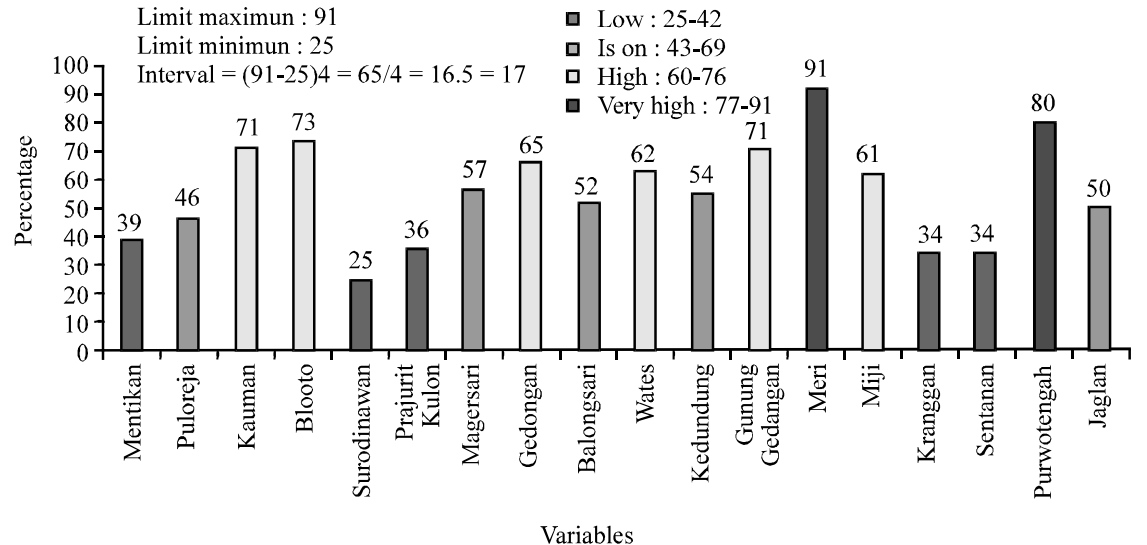

Fig. 4: Graphic of the sanitation risk index of domestic waterwaste
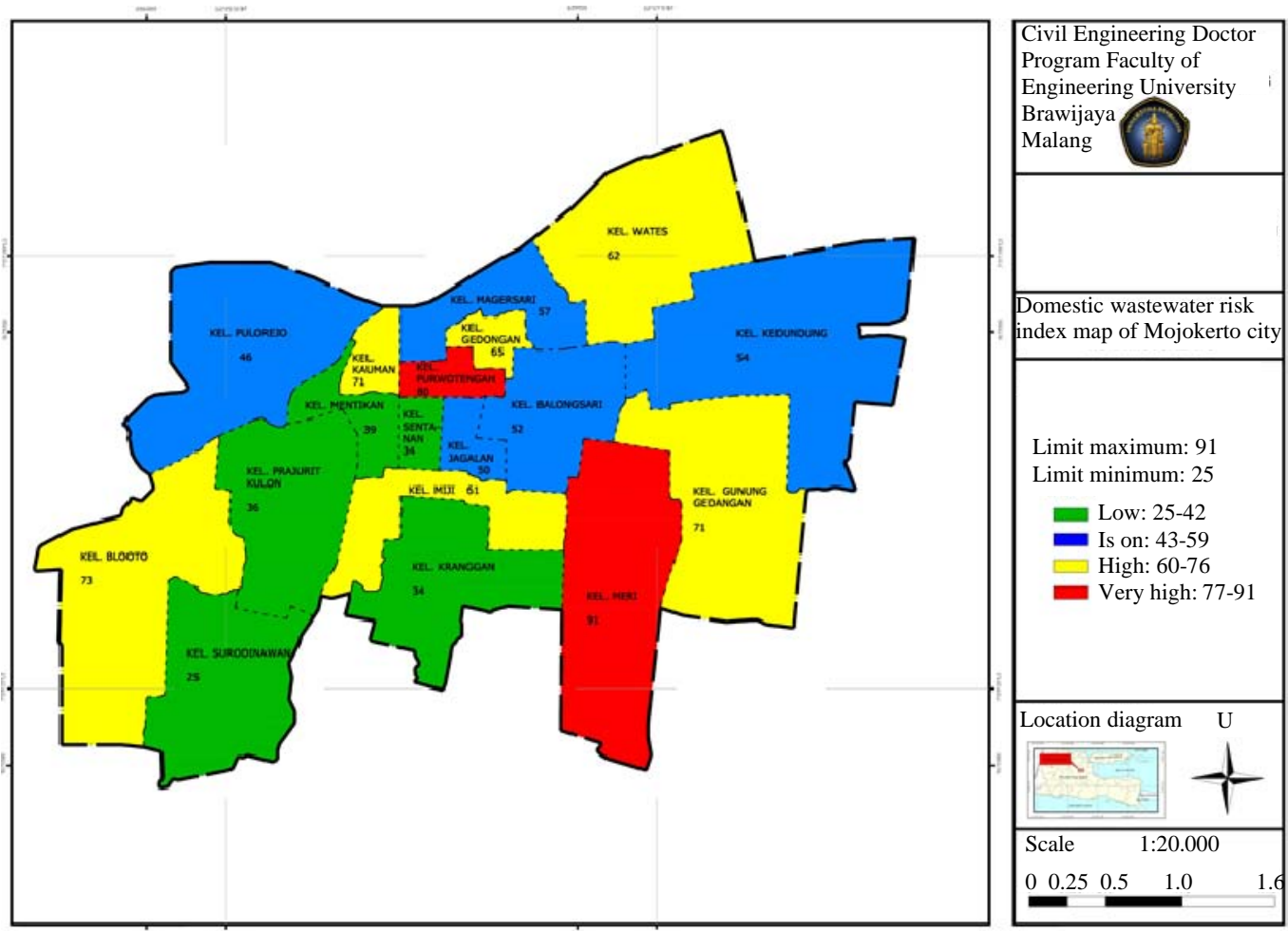

Fig. 5: Risk index map of domestic waterwaste

Based on the risk assessment of domestic waterwaste based on public participation, the domestic waterwaste management services in Mojokerto City that has very high and high risks index are:

Meri dan purwotengah administrative villages, very high risk index: The level of public participation in Meri and Puwotengah administrative villages is very low, Meri administrative village spatially interacts with Gunung Gedangan and Miji administrative villages that have a very high risk index, so that, it affects the low level of domestic waterwaste management. Part of it is side by side with Kranggan administrative village that has a low risk, therefore, the chance of improve in domestic waterwaste management will be achieved. Purwotengah administrative village spatially interacts with Kauman and Gedongan administrative village that have a very high risk 
index, so that, it affects the low level of domestic waterwaste management. Part of it is side by side with Sentanan administrative village that has a low risk, therefore, the chance of improve in domestic waterwaste management will be achieved.

Administrative villages of Kauman, Blotoo, Gedongan, Wates, Gunung Gedangan and Miji, high risk index: Medium public participation in the administrative villages of Kauman, Blotoo, Gedongan, Wates, Gunung Gedangan and Miji sedang. Kauman administrative village spatially interacts with Purwotengah administrative village that have a very high risk index, so that, it affects the low level of domestic waterwaste management. Part of it is side by side with Mentikan administrative village that has a low risk, therefore, the chance of improve in domestic waterwaste management will be achieved. Gedongan administrative village spatially interacts with Purwotengah Administrative Village that have a very high risk index, so that, it affects the low level of domestic waterwaste management. Gunung Gedangan administrative village spatially interacts with Meri administrative village that have a very high risk index, so that, it affects the low level of domestic waterwaste management. Miji administrative village spatially interacts with Kranggan, Mentikan, Prajurit Kulon and Sentanan administrative villages that have a low risk index, thus, there is a chance to an improvement in domestic waterwaste management even though its small part adjoins with Meri Administrative Village that has a very high risk index, therefore, affecting the low level of domestic waterwaste management. Blooto spatially interacts spatially interacts with Kulon and Surodinawan administrative villages that have a low risk index, so that, there is a chance to an improvement in domestic waterwaste management. Wates administrative village spatially interacts with Magersari, Balongsari, Kedundung administrative villages that have a medium risk index, so that, there is a chance to an improvement in domestic waterwaste management. The analysis result of the questionnaires, interviews and observation related to household waste management includes:

- $81.9 \%$ is collected and disposed to TPS

- $7.5 \%$ is burned

- $7.4 \%$ is collected by informal collectors who recycle

- $1.0 \%$ others

- $0.7 \%$ is dumped into river

- $\quad 0.7 \%$ is dumped into open ground holes

- $0.6 \%$ is dumped into empty land and left to rot

- $0.3 \%$ is dumped into holes and covered with ground

- Household waste separation behavior is $43 \%$ separate the waste while the rest $58 \%$ do not do so, before the further process

The domestic waterwaste management system in Mojokerto City consists of 3 systems such as: unhandled waste, handled household waste and final processing of handled waste and waste reduction. The number of landfills transported to TPA is $81.9 \%$ or $308.36 \mathrm{~m}^{3} /$ day.

The waste management analysis result, frequency of waste disposal, time accuracy of waste disposal and local waste management are (Fig. 6-9):

Based on the data above, it is conducted an analysis on the sanitation risk assessment in household waste management with the results in forms of a value and risk index mapping (Fig. 10).

a Yes enough (\%) a Not enough (\%)

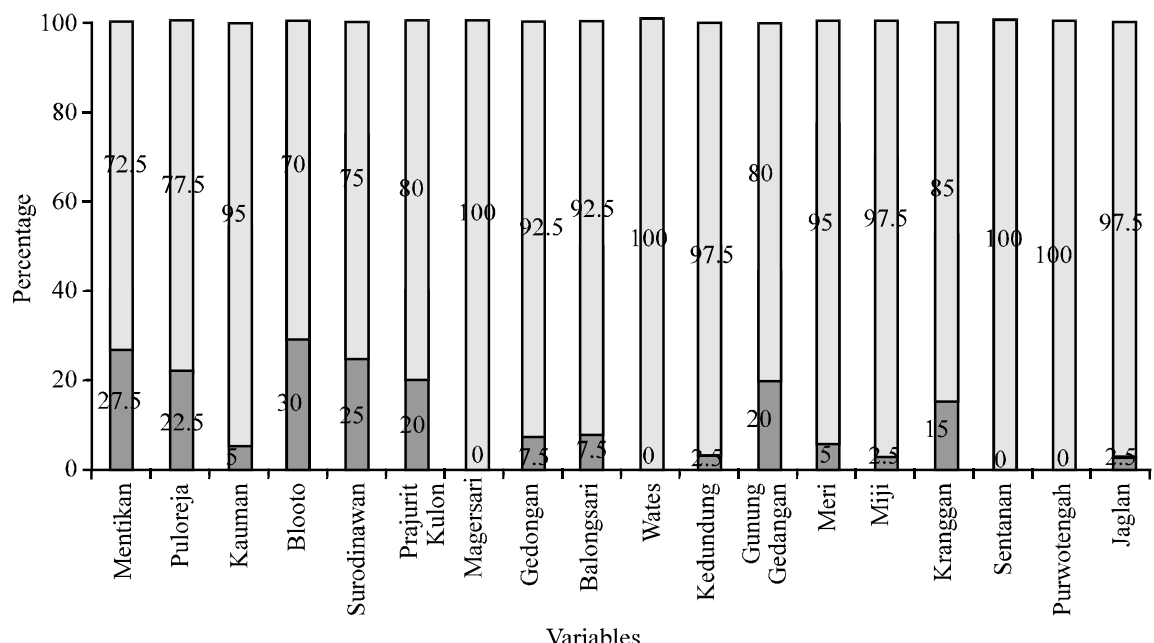

Fig. 6: Graphic of the household waste management 
J. Eng. Applied Sci., 14 (24): 9562-9572, 2019

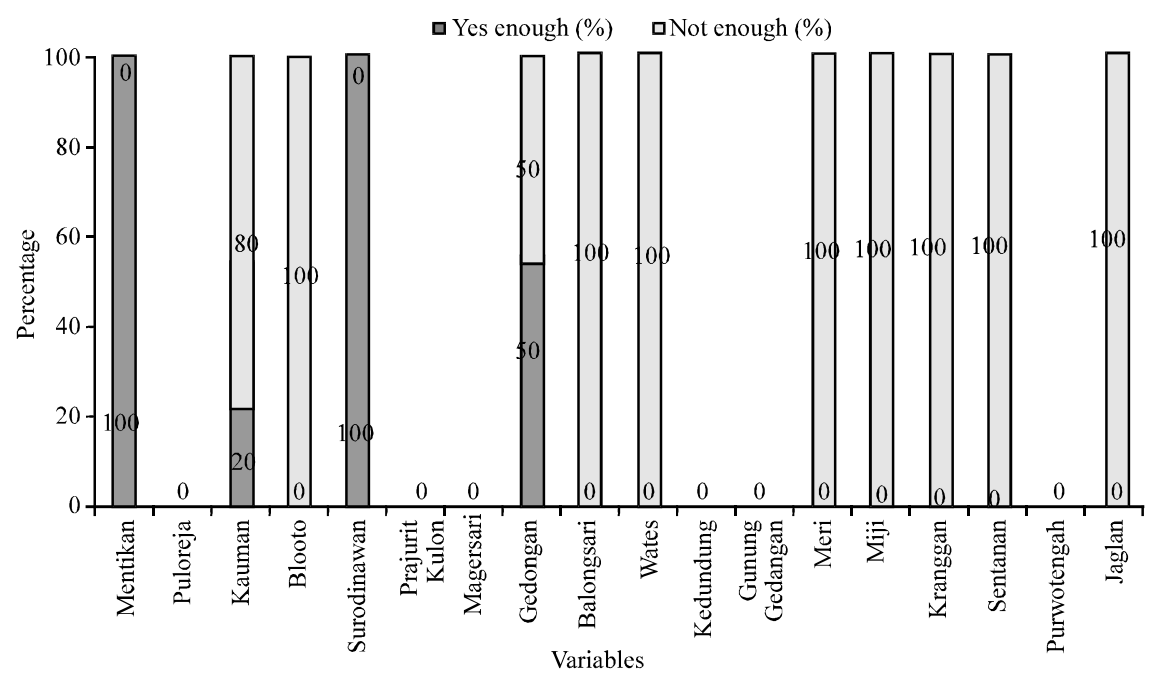

Fig. 7: Graphic of the frequency of household waste transport

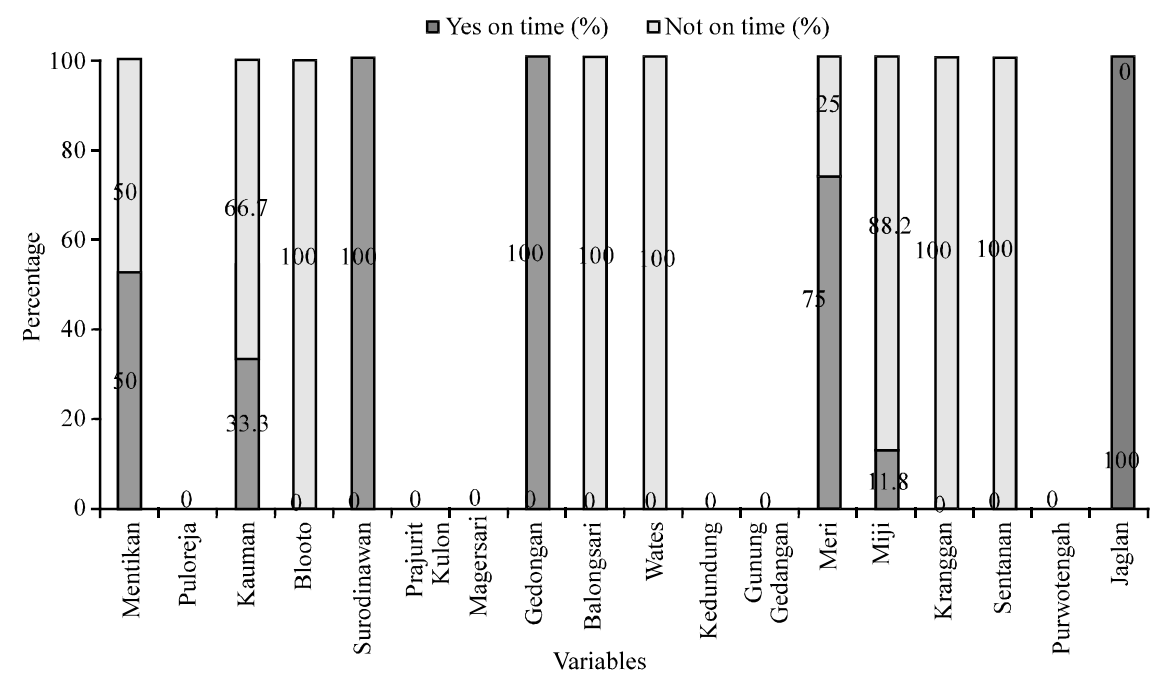

Fig. 8: Graphic of the time accuracy of household waste transport

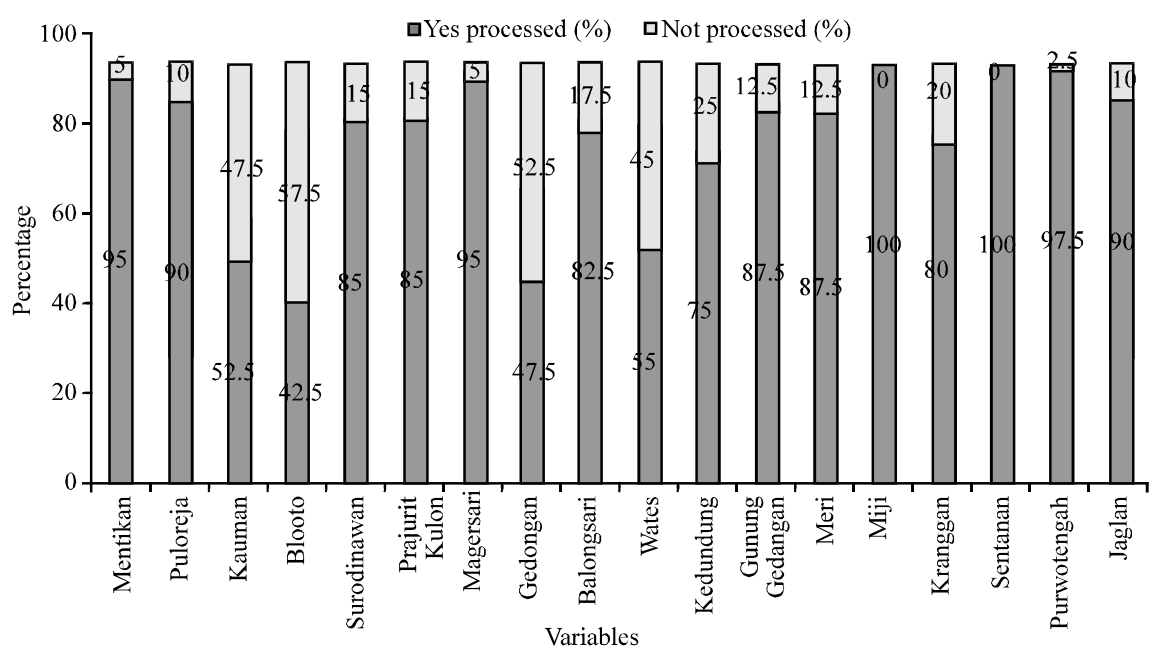

Fig. 9: Graphic of the local waste management 


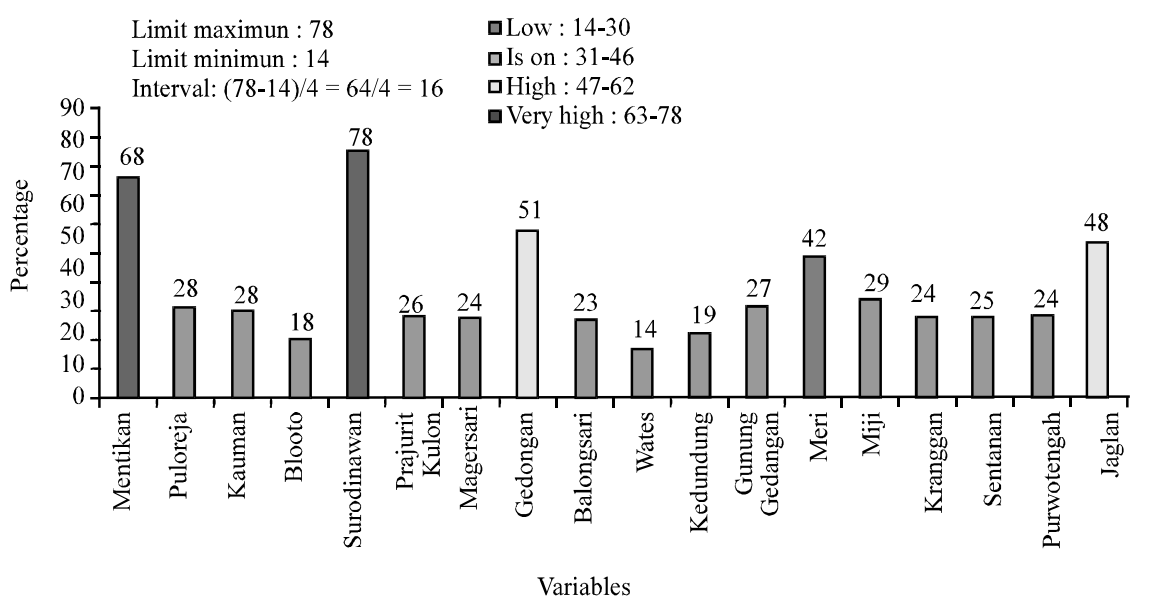

Fig. 10: Graphic of the sanitation risk index of household waste

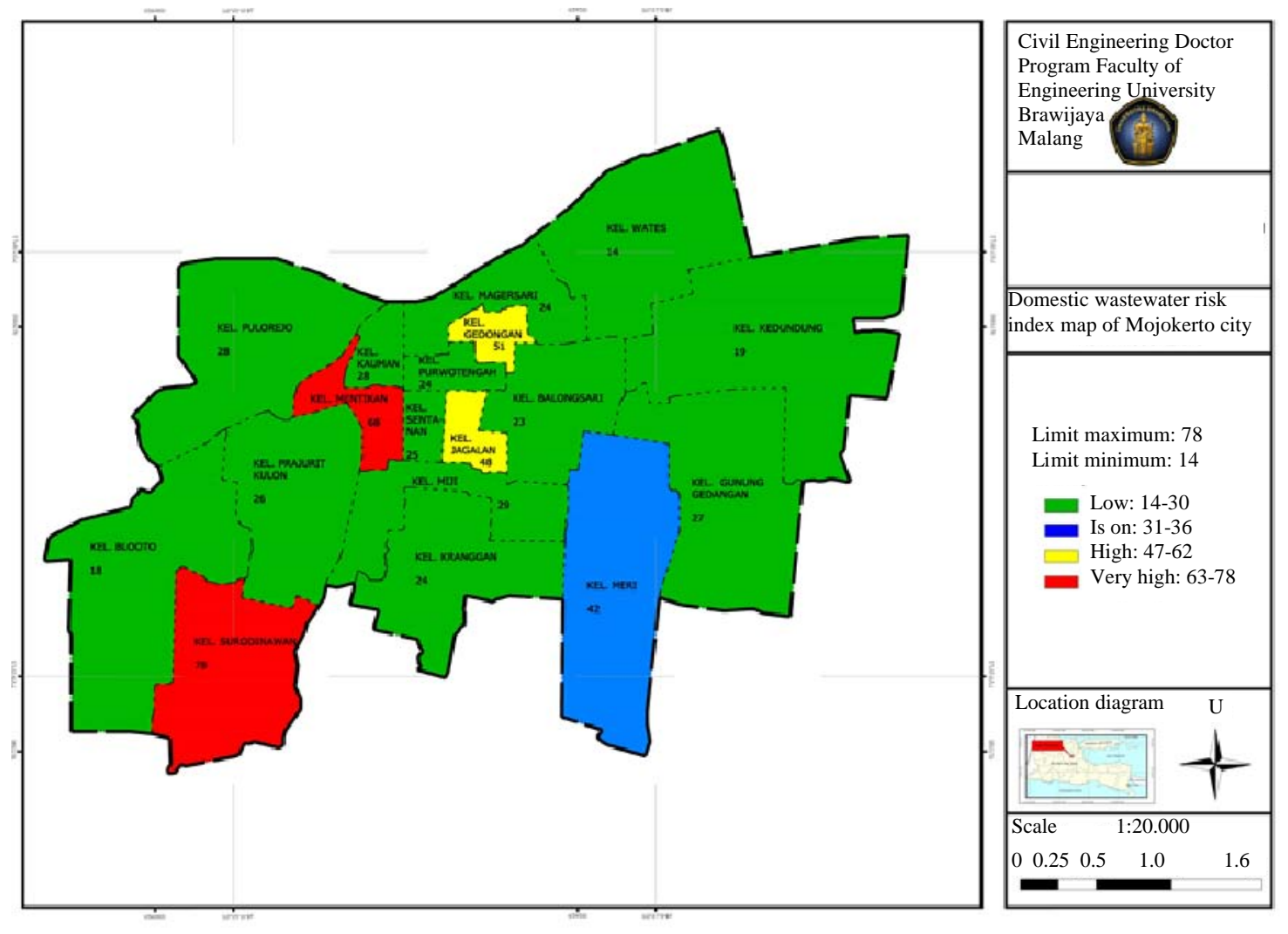

Fig. 11: The sanitation risk index map of household waste

The clarification of waste sanitation risk index using Likert scale is: maximum limit: 78 ; minimum limit: 14 ; interval: $(78-14) / 4=64 / 4=16$ (Fig. 11).

- Low risk : 14-30 (Green)

- Medium risk: 31-46 (Blue)

- High risk: 47-62 (Yellow)

- Very high risk: 63-78 (Red)
Based on the risk assessment of domestic waterwaste based on public participation, the waste services in Mojokerto City that has very high and high risks index are: Mentikan and Surodinawan administrative villages, very high risk index: the level of public participation in Mentikan and Surodinawan administrative villages is very low. Mentikan and Surodinawan administrative villages spatially interacts with administrative villages that 
have a very low risk index, thus, the a chance to an improvement in waste management to be better is very possible.

Gedongan and Jagalan administrative villages, high risk index: The level of public participation in Gedongan and Jagalan administrative villages is medium. Gedongan and Jagalan administrative villages spatially interacts with administrative villages that have a very low risk index, thus, the a chance to an improvement in waste management to be better is very possible.

\section{CONCLUSION}

Based on the analysis result and research objectives, several findings can be concluded as follows: in the method of participative process using the approach process of Methodology Participatory Assessment (MPA), acquired levels of public participation on the contrary with the results of sanitation risk index value in domestic waterwaste and household waste management: the public participation levels in domestic waterwaste management are:

- Very high participation: 25-42 (Green)

- High participation: 43-59 (Blue)

- Medium participation: 60-76 (Yellow)

- Low participation: 77-91 (Red)

The public participation levels in household waste management are:

- Very high participation: $14-30$ (Green)

- High participation: 31-46 (Blue)

- Medium participation: 47-62 (Yellow)

- Low participation: 63-78 (Red)

In spatial approach using interactive spatial approach to areas close to each other will be very influential to other areas and using comparative spatial approach, it can be described the comparison between areas in terms of domestic waterwaste or household waste management.

\section{ACKNOWLEDGEMENT}

This research was supported/partially supported by Kementerian Riset Teknologi dan Pendidikan Tinggi Republik Indonesia. We thank our colleagues from Universitas Brawijaya Malang who provided insight and expertise that greatly assisted the research, although, they may not agree with all of the interpretations/conclusions of this study.
We would also like to show our gratitude to the Prof. Ir. Respati, M. Eng. Ph.D, Dr. Ir. Wahid Hasyim, MSP, Dr. Wara Indira Rukmi, ST. MT. for sharing their pearls of wisdom with us during the course of this research and we thank "Anonymous" reviewers for their so-called insights. We are also immensely grateful to Aulia Luqman Aziz and partners for their comments on an earlier version of the manuscript, although, any errors are our own and should not tarnish the reputations of these esteemed persons.

\section{REFERENCES}

Anonymous, 2010. [Reference book for sanitation system and technology options]. Trinidad and Tobago Police Service, Jakarta, Indonesia (In Indonesian).

Anonymous, 2016. [Practical guidelines for implementing environmental health risk assessments]. Kementerian Kesehatan RI, Jakarta, Indonesia. (In Indonesian)

Anonymous, 2017. [City of mojokerto in figures]. Badan Pusat Statistik Kota Mojokerto, Mojokerto, Indonesia (In Indonesian).

Anonymous, 2017. [Implementation of domestic wastewater management systems]. Peraturan Menteri PUPR, Indonesia (In Indonesia).

Anonymous, 2017. [Sanitation strategy for Mojokerto City 2017-2021 ]. Pokja Sanitasi Kota Mojokerto, Kota Mojokerto (In Indonesian).

Arikunto, S., 2006. [Research Procedure]. Rineka Cipta, Jakarta, Indonesia (In Indonesian).

Ginige, T., N. Sparks and S. Formosa, 2010. Waste not want not-sustainable waste management in Malta. Law Environ. Dev. J., 6: 354-368.

Kombaitan, S.B., 1998. [Participatory approach in urban planning (In Indonesian)]. J. Reg. City Plann., 9: $60-70$.

Luthi, C., J. McConville, A. Norstrom, A. Panesar and R. Ingle et al., 2010. Rethinking sustainable sanitation for the urban domain. Proceedings of the International Conference on Water Environment Federation, Cities of the Future/Urban River Restoration, January 1, 2010, World Economic Forum, Switzerland, Europe, pp: 449-465.

Mardikanto, T., 1988. [Community Participation in Development]. Universitas Sebelas Maret, Surakarta, Indonesia (In Indonesian).

Nurcholis, H., 2009. [Local Government Participatory Planning]. Grasindo Publisher, Jakarta, Indonesia, ISBN:9789790257627, Pages: 177 (In Indonesia). 
Riyadi and D.S. Bratakusumah, 2004. [Regional Development Planning: Strategy to Explore Potentials in Realizing Regional Autonomy]. PT Gramedia Pustaka Utama, Jakarta, Indonesia (In Indonesian).
Rizani, M.D., 2016. [Waste management strategy in Urban areas to achieve the service target (A Case Study on Waste Management in Mojokerto, Indonesia) (In Indonesian)]. J. Appl. Sci. Res., 12: 18-22. 